\title{
PENERAPAN PROGRAM LINIER DALAM PENGOPTIMASIAN KEUNTUNGAN PRODUKSI DI HOME INDUSTRY COMOD COOKIES MENGGUNAKAN METODE KUHN-TUCKER
}

\section{The Applicated of Linier Programming in the Production Profit Optimization in Home Industry Comod Cookies by the Kuhn-Tucker Method}

\author{
Mardiyanti $^{1 *}$, Risang Narendra ${ }^{2}$, Ardhi Sanwidi ${ }^{3}$ \\ ${ }^{1,2,3}$ Program Studi Matematika, Fakultas Ilmu Eksakta, Universitas Nahdlatul Ulama Blitar \\ Jln. Masjid No. 22, Kauman, Kota Blitar, 66117, Indonesia \\ Corresponding author e-mail: 1* mardiyanti8699@gmail.com
}

\begin{abstract}
Abstrak
Penelitian ini memiliki tujuan untuk optimasi keuntungan produksi kue kering di Home Industry Comod Cookies dengan membentuk program linier yang fungsi tujuannya yaitu memaksimumkan keuntungan produksi 7 jenis kue kering dan fungsi kendala berupa bahan baku produk kue kering dalam kemasan 250 gram dan jumlah produk kue kering yang dihasilkan. Data yang digunakan dalam optimasi ini yaitu data produksi kue kering di Home Industry Comod Cookies pada tahun 2019. Metode yang digunakan dalam optimasi ini, yaitu metode Kuhn-Tucker. Hasil penyelesaian optimasi keuntungan produksi kue kering dengan metode Kuhn-Tucker yaitu keuntungan yang maksimal/tertinggi sebesar Rp. 21.122.500,00 dalam produksi 7 jenis kue kering, yang meliputi Rambutan Cookies sebanyak 500 kemasan, Cheerful Chips sebanyak 900 kemasan, Laugh Nut sebanyak 250 kemasan, Snowny Cheese sebanyak 300 kemasan, Cheese Cookies sebanyak 300 kemasan, Happy Corn sebanyak 500 kemasan, dan Nastar Cookies sebanyak 500 kemasan. Berdasarkan hasil penyelesaian optimasi dapat diberikan kesimpulan bahwa keuntungan/laba produksi kue kering di Home Industry Comod Cookies sudah optimal.
\end{abstract}

Kata Kunci : Program Linier, Optimasi, Keuntungan, Produksi, Metode Kuhn-Tucker.

\begin{abstract}
This research has the purpose to the optimization of the cookies production profit in Home Industry Comod Cookies with the forming of linier programming it purposed function is a maximizing of production profit the 7 types of cookies and the constraints function is a raw material for cookies production in 250 gram of packages and the number of cookies products produced. The data which is used in this optimization is a cookies production data on the Home Industry Comod Cookies in 2019. The method which is used in this optimization is Kuhn-Tucker method. The result of the cookies production optimization by the Kuhn-Tucker method is a maximum or highest profits is Rp. 21,122,500.00 in the production of 7 types of cookies, which include 500 packs of Rambutan Cookies, 900 packs of Cheerful Chips, 250 packs of Laugh Nut, 300 packs of Snowny Cheese, 300 packs of Cheese Cookies, 500 packs of Happy Corn, and 500 packs of Nastar Cookies. The based on the result of optimization it can be conclused that the cookies production profits in the Home Industry Comod Cookies has been optimal.
\end{abstract}

Keywords: Linear Programming, Optimization, Profit, Production, Kuhn-Tucker Method.

How to cite this article:

M. Mardiyanti, R. Narendra, and A. Sanwidi, "PENERAPAN PROGRAM LINIER DALAM PENGOPTIMASIAN KEUNTUNGAN PRODUKSI DI HOME INDUSTRY COMOD COOKIES MENGGUNAKAN METODE KUHN-TUCKER”, BAREKENG: J. Il. Mat. \& Ter., vol. 15 , no. 03, pp. 427-440, Sep. 2021.

This work is licensed under a Creative Commons Attribution-ShareAlike 4.0 International License. Copyright $\odot 2021$ Mardiyanti Mardiyanti, Risang Narendra, Ardhi Sanwidi 


\section{PENDAHULUAN}

Menurut Subandi [1], pembangunan ekonomi yaitu suatu aktivitas yang dilakukan oleh suatu Wilayah/Negara dengan tujuan untuk mengembangkan aktivitas ekonomi dalam meningkatkan taraf kehidupan/kemakmuran (Income Per-kapita) untuk jangka panjang. Perdagangan merupakan aktivitas ekonomi yang berperan penting dalam perusahaan dan berkaitan dengan jual-beli barang. Kegiatan jual-beli barang memiliki tujuan untuk mendapatkan laba/keuntungan. Dengan laba/keuntungan, maka dapat digunakan dalam memenuhi kebutuhan hidup sehari-hari [2].

Menurut Moengin [2], banyaknya persaingan dalam perdagangan, sehingga membuat pedagang/pengusaha harus memiliki strategi yang tepat dengan tujuan proses perdagangan berjalan lancar dan mendapatkan keuntungan yang maksimum/tertinggi. Namun berbagai permasalahan muncul dalam perdagangan yaitu tidak stabilnya antara jumlah pengeluaran dan jumlah pemasukan, sehingga menyebabkan nilai produksi tidak optimal. Optimal yang dimaksud adalah suatu kegiatan untuk memperoleh keuntungan maksimum/tertinggi dibawah permasalahan produksi yang dihadapi. Sama halnya seperti tujuan optimasi adalah memperoleh hasil yang optimal baik maksimal maupun minimal. Secara teori optimasi dibedakan menjadi 2 jenis, yaitu optimasi dengan kendala dan tanpa kendala. Penerapan masalah optimasi akan dilakukan di Home Industry Comod Cookies yang beralamat di Kecamatan Ponggok. Dalam buku [3] yang bersumber pada Dinas Perdagangan dan Perindustrian di Kabupaten Blitar, Kecamatan Ponggok merupakan kecamatan yang memiliki Industri makanan/minuman cukup tinggi di Kabupaten blitar sebesar 2.120 industri. Cookies adalah salah satu makanan ringan yang populer di masyarakat dan digemari oleh hampir semua orang, sehingga tidak heran jika di masyarakat cookies memiiki tingkat konsumsi yang tinggi [4].

Permasalahan optimasi keuntungan produksi di Home Industry Comod Cookies dilakukan dengan penerapan program linier. Program linier merupakan metode matematika yang memiliki hubungan dengan masalah optimasi yaitu maksimalkan ataupun minimalkan suatu fungsi tujuan (x) dibawah sumber daya (variabel input) yang ada [5]. Menurut Herjanto [1],[6], karena tingkat keuntungan, faktor produksi, dan jenis produk yang diproduksi oleh perusahaan/industri mempunyai hubungan yang linier, sehingga optimasi dapat dilakukan dengan program linier menggunakan metode simpleks. Pada metode simpleks, untuk mencari solusi optimal digunakan dengan tahap pengulangan atau iterasi yang diawali dengan pengerjaan dasar awal yang layak hingga pengerjaan dasar akhir yang layak, yang mana nilai fungsi tujuan menghasilkan solusi optimal [7]. Namun, apabila digunakan pada kendala/pembatas yang banyak maupun kompleks, maka metode simpleks dirasa kurang efisien, sebab banyaknya iterasi yang diperoleh akan mengakibatkan waktu perhitungan yang lama [8]. Menurut Purcell [9], metode matematika pada permasalahan optimasi juga terdapat dalam teori optimasi di kalkulus yaitu metode pengali Lagrange. Sedangkan dengan kendala/pembatas berupa pertidaksamaan yaitu metode Kuhn-Tucker. Dalam optimasi ini kendala/pembatas yang digunakan berbentuk pertidaksamaan, sehingga metode yang digunakan yaitu metode Kuhn-Tucker.

Metode Kuhn-Tucker yaitu metode optimasi suatu fungsi tujuan dengan pembatas/kendala yang berbentuk pertidaksamaan. Metode ini mengembangkan metode Lagrange dalam optimasi dengan kendala/pembatas pertidaksamaan. Metode Lagrange juga dapat digunakan dalam optimasi yang berbentuk pertidaksamaan, apabila diberikan syarat perlu dan syarat cukup Kuhn-Tucker. Metode Kuhn-Tucker juga dapat digunakan dalam penyelesaian nilai optimal (maksimal atau minimal) suatu fungsi tanpa melihat fungsi linier dan nonlinier [10]. Proses penyelesaian metode Kuhn-Tucker tidak menggunakan iterasi, melainkan membentuk fungsi Lagrangian, mencari nilai $\left(x_{i}, \lambda_{i}, S_{i}\right)$, dan menghitung nilai $f(x)$, dimana nilai $x$ berada pada himpunan $\left\{x \mid\right.$ ada $\lambda$ sedemikian sehingga $\left.\left(x_{i}, \lambda_{i}, S_{i}\right) \in M\right\}[9]$.

Penelitian ini didasarkan pada penelitian sebelumnya. Penelitian oleh I Gede Aris Janova Putra, dkk dalam optimasi kain endek di toko Navala Busana dan Trans Collaction. Hasil penelitian oleh I Gede Aris Janova Putra, dkk yaitu dapat menggunakan metode Kuhn-Tucker sebagai optimasi keuntungan 5 jenis kain endek di toko Navala Busana dan Trans Collaction [11]. Penelitian oleh Ni M. Asih dan I Nyoman W. dalam optimasi penjualan oli mobil di PT. Anugrah Mitra Dewata, Bali. Hasil Penelitian oleh Ni M. Asih dan I Nyoman W. yaitu dapat menggunakan metode Kuhn-Tucker sebagai optimasi keuntungan penjualan 6 jenis oli mobil di PT. Anugrah Mitra Dewata, Bali [9]. Sehingga, tujuan penelitian ini yaitu optimasi keuntungan produksi kue kering di Home Industry Comod Cookies menggunakan metode Kuhn-Tucker dengan membentuk program linier yang fungsi tujuannya yaitu keuntungan 7 jenis produk kue kering. 


\section{METODE PENELITIAN}

Data yang digunakan pada optimasi ini yaitu data produksi kue kering pada tahun 2019 di Home Industry Comod Cookies. Data dalam optimasi ini merupakan data sekunder. Data sekunder yaitu suatu data yang didapatkan dengan cara tidak langsung, melainkan harus diperoleh dengan pencarian secara mendalam melalui internet, literatur, statistik, buku, dan sejenisnya [12]. Adapun data sekunder dalam optimasi ini didapatkan melalui dokumen data produksi kue kering di Home Industry Comod Cookies yang beralamatkan di Desa Jagoan Kecamatan Ponggok Kabupaten Blitar. Data yang didapatkan kemudian divalidasi oleh pemilik Home Industry Comod Cookies. Optimasi ini menggunakan angka (bilangan), dari awal pengumpulan data, analisis data, sampai dengan hasil optimasi yang diperoleh, sehingga pendekatan penelitian dalam optimasi ini disebut pendekatan penelitian kuantitatif [13]. Metode penelitian dalam penyelesaian optimasi ini, ialah metode Kuhn-Tucker.

Berikut ini tahapan metode Kuhn-Tucker dalam penyelesaian masalah optimasi [10] :

1. Membentuk variabel keputusan (x), yaitu variabel yang berhubungan dengan keputusan yang digunakan dalam permasalahan optimasi [14].

2. Membentuk fungsi tujuan, yaitu fungsi pada variabel keputusan (x) yang dimaksimalkan ataupun diminimalkan [14].

3. Membentuk fungsi kendala/pembatas, yaitu fungsi dari kendala/pembatas yang dihadapi perusahaan, sehingga nilai (koefisien) pada variabel keputusan tidak dapat ditentukan dengan sembarang [14].

4. Membentuk model matematika program linier, yaitu metode matematika yang digunakan pada pengalokasian sumber daya (kebutuhan) yang memiliki batasan/kendala dalam mencapai tujuan, yakni memaksimalkan keuntungan/laba atau meminimalkan biaya [1]. Bentuk umum program linier [15]:

a. Fungsi tujuan $(f(x))$

Maksimalkan atau minimalkan $f(x)=z=c_{1} x_{1}+c_{2} x_{2}+\ldots+c_{n}$

b. Fungsi kendala/pembatas $(g(x))$

$a_{11} x_{1}+a_{12} x_{2}+\ldots+a_{1 n} x_{n}=/ \leq / \geq b_{1}$

$a_{21} x_{1}+a_{22} x_{2}+\ldots+a_{2 n} x_{n}=/ \leq / \geq b_{2}$

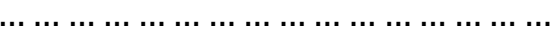

$a_{m 1} x_{1}+a_{m 2} x_{2}+\ldots+a_{m n} x_{n}=/ \leq / \geq b_{n}$

$x_{1}, x_{2}, \ldots, x_{n} \geq 0$

Keterangan :

$c_{1}, c_{2}, \ldots, c_{n} \quad=$ Keuntungan produksi $\quad a_{11}, a_{21}, \ldots, a_{m n}=$ Banyak bahan baku produksi

$x_{1}, x_{2}, \ldots, x_{n} \quad=$ Variabel keputusan produksi $b_{1}, b_{2}, \ldots, b_{n}=$ Persediaan bahan produksi

5. Menyelesaikan masalah optimasi menggunakan metode Kuhn-Tucker dengan langkah berikut [10] :

a. Mengubah kendala pertidaksamaan pada program linier menjadi kendala persamaan dengan cara menambah variabel slack $\left(S_{i}^{2}\right)$

b. Membentuk persamaan menjadi fungsi Lagrange, sehingga menjadi persamaan (1) berikut :

$$
L(x, \lambda, S)=f(x)+\sum_{i=1}^{m} \lambda_{i} g_{i}(x) \mathrm{b}+\mathrm{S}_{\mathrm{i}}^{2}
$$

Keterangan :
$L(x, \lambda, S)$ : fungsi Lagrange atau lagrangian
$\mathrm{x} \quad$ : variabel keputusan
$\mathrm{f}(\mathrm{x}) \quad$ : fungsi tujuan dalam optimasi.
$g_{i}(x) \quad$ : fungsi kendala
$\mathrm{m} \quad$ : banyak fungsi kendala
$\lambda_{i} \quad$ : pengali Lagrange
$\mathrm{b} \quad$ : nilai kanan pada fungsi kendala.
$S_{i}^{2} \quad$ : variabel slack

c. Merubah fungsi Lagrange menjadi persamaan Kuhn-Tucker, sehingga menjadi persamaan (2), (3), dan (4) berikut :
$\frac{\partial \mathrm{L}}{\partial \mathrm{x}_{\mathrm{i}}}(x, \lambda, S)=0$
$\frac{\partial \mathrm{L}}{\partial \lambda_{\mathrm{i}}}(x, \lambda, S)=0$
$\frac{\partial \mathrm{L}}{\partial \mathrm{S}_{\mathrm{i}}}(x, \lambda, S)=0$

Keterangan :

$\frac{\partial \mathrm{L}}{\partial \mathrm{x}_{\mathrm{i}}}, \frac{\partial \mathrm{L}}{\partial \lambda_{\mathrm{i}}}, \frac{\partial \mathrm{L}}{\partial \mathrm{S}_{\mathrm{i}}}$ : turunan pertama fungsi Lagrange terhadap variabel keputusan ke i, terhadap pengali Lagrange ke i, dan terhadap variabel slack ke i, dimana i yaitu $1,2, \ldots, \mathrm{m}$.

d. Dari persamaan fungsi Kuhn-Tucker, akan mendapatkan nilai $\left(x_{i}, \lambda_{i}, S_{i}\right)$ yang memenuhi yarat perlu (penting) dan syarat cukup (memenuhi) Kuhn-Tucker. Syarat perlu metode Kuhn-Tucker [10], yaitu :
$\frac{\partial \mathrm{L}}{\partial \mathrm{x}_{\mathrm{i}}}=\frac{\partial \mathrm{L}}{\partial \mathrm{x}_{\mathrm{i}}}+\sum_{\mathrm{i}=1}^{\mathrm{m}} \lambda_{\mathrm{i}} \frac{\partial \mathrm{L}}{\partial \mathrm{x}_{\mathrm{i}}}=0$
(5)
$\lambda_{\mathrm{i}} \mathrm{g}_{\mathrm{i}}=0$
(6)
(x) $\leq 0$ 
$\lambda_{\mathrm{i}}$ tidak terbatas tanda dan nilai i adalah $1,2,3,4 \ldots, \mathrm{m}$. Sedangkan syarat cukup metode Kuhn-Tucker, yaitu :

Tabel 1. Syarat Cukup Metode Kuhn-Tucker

\begin{tabular}{|c|c|c|c|}
\hline \multirow[b]{2}{*}{ Jenis Optimasi } & \multicolumn{3}{|c|}{ Syarat cukup metode Kuhn Tucker } \\
\hline & $f(x)$ & $\mathrm{gi}_{\mathrm{i}}(\mathrm{x})$ & $\lambda_{i}$ \\
\hline Maksimalkan & $\begin{array}{c}\text { Konkaf } \\
\text { (cekung) }\end{array}$ & $\left\{\begin{array}{c}\text { Konveks } \\
\text { Konkaf } \\
\text { Linier }\end{array}\right.$ & $\begin{array}{l}\geq 0(\mathrm{i}=1,2, \ldots, \mathrm{m}) \\
\leq 0(\mathrm{i}=\mathrm{m}+1, \ldots, \mathrm{n}) \\
\text { Tidak terbatas tanda }(\mathrm{i}=\mathrm{n}+1, \mathrm{n}+2, \ldots, \mathrm{p})\end{array}$ \\
\hline Minimalkan & $\begin{array}{l}\text { Konveks } \\
\text { (cembung) }\end{array}$ & $\left\{\begin{array}{c}\text { Konveks } \\
\text { Konkaf } \\
\text { Linier }\end{array}\right.$ & $\begin{array}{l}\geq 0(\mathrm{i}=1,2, \ldots, \mathrm{m}) \\
\leq 0(\mathrm{i}=\mathrm{m}+1, \ldots, \mathrm{n}) \\
\text { Tidak terbatas tanda }(\mathrm{i}=\mathrm{n}+1, \mathrm{n}+2, \ldots, \mathrm{p})\end{array}$ \\
\hline
\end{tabular}

Selain itu, syarat cukup metode Kuhn-Tucker pada fungsi linier, yaitu nilai $\lambda_{i}$ tidak dibatasi oleh tanda yang artinya $\lambda_{i} \geq 0$ dan $\lambda_{i} \leq 0$ [10].

e. Menghitung nilai keuntungan yang maksimal/tertinggi dengan mensubtitusikan/memasukkan nilai $\left(x_{i}, \lambda_{i}, S_{i}\right)$ kedalam fungsi Lagrange berikut :

$\left.\left.\left.L\left(x_{i}, \lambda_{i}, S_{i}\right)=f(x)+\sum_{i}^{m} \lambda_{i}\left[g_{i}(x)+S_{i}^{2}\right)\right]+\sum_{i=m+1}^{n} \lambda_{i}\left[g_{i}(x)+S_{i}^{2}\right)\right]+\sum_{i=n}^{p} \lambda_{i}\left[g_{i}(x)+S_{i}^{2}\right)\right]$

6. Mengambil kesimpulan yang didapatkan dari hasil penelitian permasalahan.

\section{HASIL DAN PEMBAHASAN}

\subsection{Model Matematika Program Linier}

\subsubsection{Membentuk Variabel Keputusan}

Variabel keputusan dalam optimasi ini yaitu 7 jenis produk kue kering yang dihasilkan di Home Industry Comod Cookies pada tahun 2019, yaitu Rambutan Cookies $\left(x_{1}\right)$, Cheerful Chips $\left(x_{2}\right)$, Laugh Nut $\left(x_{3}\right)$, Snowny Cheese $\left(x_{4}\right)$, Cheese Cookies $\left(x_{5}\right)$, Happy Corn $\left(x_{6}\right)$, dan Nastar Cookies $\left(x_{7}\right)$.

\subsubsection{Membentuk Fungsi Tujuan}

Fungsi tujuan dalam optimasi ini yaitu keuntungan produksi kue kering dalam kemasan 250 gram di Home Industry Comod Cookies Tahun 2019. Keuntungan tersebut dapat disajikan dalam Tabel 2, berikut:

Tabel 2 . Keuntungan produksi kue kering di Home Industry Comod Cookies pada Tahun 2019

\begin{tabular}{lccc}
\hline Produk Kue Kering & $\begin{array}{c}\text { Rata-Rata Harga Jual } \\
\text { (Rp) }\end{array}$ & $\begin{array}{c}\text { Rata-Rata Biaya } \\
\text { Produksi (Rp) }\end{array}$ & $\begin{array}{c}\text { Keuntungan Produksi } \\
\text { Kue Kering (Rp) }\end{array}$ \\
\hline Rambutan Cookies & 35.000 & 24.300 & 10.700 \\
\hline Cheerful Chips & 35.000 & 31.600 & 3.600 \\
\hline Laugh Nut & 35.000 & 28.550 & 6.450 \\
\hline Snowny Cheese & 35.000 & 28.700 & 6.300 \\
\hline Cheese Cookies & 35.000 & 27.300 & 7.700 \\
\hline Happy Corn & 35.000 & 28.400 & 6.600 \\
\hline Nastar Cookies & 35.000 & 27.800 & 7.200 \\
\hline
\end{tabular}

Sehingga berdasarkan tabel 2, terdapat keuntungan produksi 7 jenis kue kering yang dapat dibentuk fungsi tujuan pada persamaan (9) berikut :

$$
f(x)=10.700 x_{1}+3.400 x_{2}+6.450 x_{3}+6.300 x_{4}+7.700 x_{5}+6.600 x_{6}+7.200 x_{7}
$$

\subsubsection{Membentuk Fungsi Kendala}

Fungsi pembatas/kendala dalam optimasi ini yaitu bahan baku setiap jenis produk kue kering dalam kemasan 250 gram dan jumlah produk kue kering yang dihasilkan di Home Industry Comod Cookies pada tahun 2019. Kendala tersebut dapat disajikan dalam Tabel 3, berikut: 
Tabel 3. Bahan Baku setiap Jenis Produk Kue Kering dalam Kemasan 250 Gram

\begin{tabular}{lrrrrrrrr}
\hline \multirow{2}{*}{ Bahan Baku } & \multicolumn{7}{c}{ Jenis Produk Kue Kering (Gram) } & Persediaan \\
\cline { 2 - 8 } & $\begin{array}{c}\text { Rambutan } \\
\text { Cookies }\end{array}$ & $\begin{array}{c}\text { Cheerful } \\
\text { Chips }\end{array}$ & $\begin{array}{c}\text { Laugh } \\
\text { Nahan }\end{array}$ & $\begin{array}{c}\text { Snowny } \\
\text { Cheese }\end{array}$ & $\begin{array}{c}\text { Cheese } \\
\text { Cookies }\end{array}$ & $\begin{array}{c}\text { Happy } \\
\text { Corn }\end{array}$ & $\begin{array}{c}\text { Nastar } \\
\text { Cookies }\end{array}$ & (Gram) \\
\hline Terigu & 31,3 & 58,33 & 87,5 & 100 & 100 & 0 & 41,7 & 170850 \\
\hline Margarin & 8 & 0 & 38 & 75 & 75 & 0 & 33,3 & 75150 \\
\hline Telur & 6,3 & 16,67 & 13 & 12,5 & 37,5 & 0 & 8,3 & 40550 \\
\hline Gula & 6,3 & 20,84 & 50 & 25 & 12,5 & 0 & 8,3 & 49800 \\
\hline Coklat batang & 31,3 & 0 & 0 & 0 & 0 & 41,7 & 0 & 36500 \\
\hline Susu & 1,3 & 0,833 & 0 & 0 & 0 & 0 & 1,7 & 2250 \\
\hline Gula palm & 0 & 20,84 & 0 & 0 & 0 & 0 & 0 & 18750 \\
\hline Palmia royal & 0 & 41,67 & 0 & 0 & 0 & 0 & 0 & 37500 \\
\hline Maizena & 0 & 4,167 & 0 & 0 & 0 & 0 & 0 & 3750 \\
\hline Batter & 0 & 0 & 25 & 0 & 0 & 0 & 0 & 6250 \\
\hline Kacang & 0 & 0 & 62,5 & 0 & 0 & 0 & 0 & 15650 \\
\hline Corn flakes & 0 & 0 & 0 & 0 & 0 & 50 & 0 & 25000 \\
\hline Keju & 0 & 0 & 0 & 12,5 & 37,5 & 0 & 0 & 15000 \\
\hline Selai nanas & 0 & 0 & 0 & 0 & 0 & 0 & 125 & 62500 \\
\hline Toping & 43,8 & 41,67 & 25 & 50 & 0 & 16,7 & 0 & 89000 \\
\hline
\end{tabular}

Tabel 4. Jumlah Produksi Kue Kering (cookies) yang Dihasilkan pada Tahun 2019

\begin{tabular}{lc}
\hline Jenis Produk Kue Kering & Jumlah Produk kue kering (cookies) (kemasan) \\
\hline Rambutan Cookies & 500 \\
\hline Cheerful Chips & 900 \\
\hline Laugh Nut & 250 \\
\hline Snowny Cheese & 300 \\
\hline Cheese Cookies & 300 \\
\hline Happy Corn & 500 \\
\hline Nastar Cookies & 500 \\
\hline
\end{tabular}

Berdasarkan Tabel 3 dan Tabel 4, terdapat 22 kendala/pembatas dalam produksi kue kering, sehingga dapat dibentuk fungsi kendala/pembatas pada persamaan ( 10) berikut:

$$
\begin{gathered}
31,3 x_{1}+58,33 x_{2}+87,5 x_{3}+100 x_{4}+100 x_{5}+41,7 x_{7} \leq 170.850 \\
8 x_{1}+38 x_{3}+75 x_{4}+75 x_{5}+33,3 x_{7} \leq 75.150 \\
6,3 x_{1}+16,7 x_{2}+13 x_{3}+12,5 x_{4}+37,5 x_{5}+8,3 x_{7} \leq 40.550 \\
6,3 x_{1}+20,84 x_{2}+50 x_{3}+25 x_{4}+12,5 x_{5}+8,3 x_{7} \leq 49.800 \\
31,3 x_{1}+41,7 x_{6} \leq 36.500 \\
1,3 x_{1}+0,833 x_{2}+1,7 x_{7} \leq 2.250 \\
20,84 x_{2} \leq 18.750 \\
41,67 x_{2} \leq 37500 \\
4,167 x_{2} \leq 3.750 \\
25 x_{3} \leq 6250 \\
62,5 x_{3} \leq 15.650 \\
50 x_{6} \leq 25.000 \\
12,5 x_{4}+37,5 x_{5} \leq 15.000 \\
125 x_{7} \leq 62.500 \\
x_{1} \leq 500 \\
x_{2} \leq 900 \\
x_{3} \leq 250
\end{gathered}
$$




$$
\begin{aligned}
& x_{4} \leq 300 \\
& x_{5} \leq 300 \\
& x_{6} \leq 500 \\
& x_{7} \leq 500
\end{aligned}
$$

\subsubsection{Membentuk Program Linier}

Berdasarkan persamaan (9) dan (10), dapat dibentuk program linier, sehingga diperoleh persamaan (11) berikut:

$$
\begin{gathered}
\text { Maks } z=f(x)=10.700 x_{1}+3.400 x_{2}+6.450 x_{3}+6.300 x_{4}+7.700 x_{5}+6.600 x_{6}+7.200 x_{7} \\
\text { Kendala }\left(g_{i}(x)\right): g_{1}(x)=31,3 x_{1}+58,33 x_{2}+87,5 x_{3}+100 x_{4}+100 x_{5}+41,7 x_{7} \leq 170.850 \\
g_{2}(x)=8 x_{1}+38 x_{3}+75 x_{4}+75 x_{5}+33,3 x_{7} \leq 75.150 \\
g_{3}(x)=6,3 x_{1}+16,7 x_{2}+13 x_{3}+12,5 x_{4}+37,5 x_{5}+8,3 x_{7} \leq 40.550 \\
g_{4}(x)=6,3 x_{1}+20,84 x_{2}+50 x_{3}+25 x_{4}+12,5 x_{5}+8,3 x_{7} \leq 49.800 \\
g_{5}(x)=31,3 x_{1}+41,7 x_{6} \leq 36.500 \\
g_{6}(x)=1,3 x_{1}+0,833 x_{2}+1,7 x_{7} \leq 2.250 \\
g_{7}(x)=20,84 x_{2} \leq 18.750 \\
g_{8}(x)=41,67 x_{2} \leq 37500 \\
g_{9}(x)=4,167 x_{2} \leq 3.750 \\
g_{10}(x)=25 x_{3} \leq 6250 \\
g_{11}(x)=62,5 x_{3} \leq 15.650 \\
g_{12}(x)=50 x_{6} \leq 25.000 \\
g_{1} 3(x)=12,5 x_{4}+37,5 x_{5} \leq 15.000 \\
g_{14}(x)=125 x_{7} \leq 62.500 \\
\left(1,67 x_{2}+25 x_{3}+50 x_{4}+16,7 x_{6} \leq 89.000\right. \\
g_{16}(x)=x_{1} \leq 500 \\
g_{17}(x)=x_{2} \leq 900 \\
g_{18}(x)=x_{3} \leq 250 \\
g_{19}(x)=x_{4} \leq 300 \\
g_{20}(x)=x_{5} \leq 300 \\
g_{21}(x)=x_{6} \leq 500 \\
g_{22}(x)=x_{7} \leq 500 \\
x_{1}, x_{2}, x_{3}, x_{4}, x_{5}, x_{6}, x_{7} \geq 0 \\
\left.g_{15}(x)=43,8 x_{1}+41\right)
\end{gathered}
$$

\subsection{Penyelesaian Program Linier dengan Metode Kuhn-Tucker}

\subsubsection{Mengubah Kendala Pertidaksamaan pada Program Linier Menjadi Kendala Persamaan}

Mengubah kendala pertidaksamaan pada persamaan (11) menjadi kendala persamaan dengan cara menambah variabel slack $\left(S_{i}^{2}\right)$,sehingga menjadi persamaan (12) berikut:

$$
\begin{gathered}
f(x)=10.700 x_{1}+3.400 x_{2}+6.450 x_{3}+6.300 x_{4}+7.700 x_{5}+6.600 x_{6}+7.200 x_{7} \\
g_{1}(x)=31,3 x_{1}+58,33 x_{2}+87,5 x_{3}+100 x_{4}+100 x_{5}+41,7 x_{7}+S_{1}^{2}=170.850 \\
g_{2}(x)=8 x_{1}+38 x_{3}+75 x_{4}+75 x_{5}+33,3 x_{7}+S_{2}^{2}=75.150 \\
g_{3}(x)=6,3 x_{1}+16,7 x_{2}+13 x_{3}+12,5 x_{4}+37,5 x_{5}+8,3 x_{7}+S_{3}^{2}=40.550 \\
g_{4}(x)=6,3 x_{1}+20,84 x_{2}+50 x_{3}+25 x_{4}+12,5 x_{5}+8,3 x_{7}+S_{4}^{2}=49.800 \\
g_{5}(x)=31,3 x_{1}+41,7 x_{6}+S_{5}^{2}=36.500 \\
g_{6}(x)=1,3 x_{1}+0,833 x_{2}+1,7 x_{7}+S_{6}^{2}=2.250 \\
g_{7}(x)=20,84 x_{2}+S_{7}^{2}=18.750 \\
g_{8}(x)=41,67 x_{2}+S_{8}^{2}=37500 \\
g_{9}(x)=4,167 x_{2}+S_{9}^{2}=3.750 \\
g_{10}(x)=25 x_{3}+S_{10}^{2}=6250 \\
g_{11}(x)=62,5 x_{3}+S_{11}^{2}=15.650 \\
g_{12}(x)=50 x_{6}+S_{12}^{2}=25.000 \\
g_{13}(x)=12,5 x_{4}+37,5 x_{5}+S_{13}^{2}=15.000 \\
g_{14}(x)=125 x_{7}+S_{14}^{2}=62.500 \\
g_{15}(x)=43,8 x_{1}+41,67 x_{2}+25 x_{3}+50 x_{4}+16,7 x_{6}+S_{15}^{2}=89.000
\end{gathered}
$$




$$
\begin{gathered}
g_{16}(x)=x_{1}+S_{16}^{2}=500 \\
g_{17}(x)=x_{2}+S_{17}^{2}=900 \\
g_{18}(x)=x_{3}+S_{18}^{2}=250 \\
g_{19}(x)=x_{4}+S_{19}^{2}=300 \\
g_{20}(x)=x_{5}+S_{20}^{2}=300 \\
g_{21}(x)=x_{6}+S_{21}^{2}=500 \\
g_{22}(x)=x_{7}+S_{22}^{2}=500 \\
x_{1}, x_{2}, x_{3}, x_{4}, x_{5}, x_{6}, x_{7}, S_{1}, S_{2}, S_{3}, S_{4}, S_{5}, S_{6}, S_{7}, S_{8}, S_{9}, S_{10}, S_{11}, \\
S_{12}, S_{13}, S_{14}, S_{15}, S_{16}, S_{17}, S_{18}, S_{19}, S_{20}, S_{21}, S_{22} \geq 0
\end{gathered}
$$

\subsubsection{Membentuk Persamaan menjadi Fungsi Lagrange}

Membentuk persamaan (12) menjadi fungsi Lagrange yang memiliki rumus $L(x, \lambda, S)=f(x)+$ $\sum_{i=1}^{m} \lambda_{i} g_{i}(x)-\mathrm{b}+\mathrm{S}_{\mathrm{i}}^{2}$, sehingga menjadi fungsi Lagrange pada persamaan (13) berikut:

$$
\begin{aligned}
\mathrm{L} & \left(x_{1}, x_{2}, x_{3}, x_{4}, x_{5}, x_{6}, x_{7}, \lambda_{1}, \lambda_{2}, \lambda_{3}, \lambda_{4}, \lambda_{5}, \lambda_{6}, \lambda_{7}, \lambda_{8}, \lambda_{9}, \lambda_{10}, \lambda_{11}, \lambda_{12}, \lambda_{13}, \lambda_{14}, \lambda_{15}, \lambda_{16}, \lambda_{17}\right. \\
, & \left.\lambda_{18}, \lambda_{19}, \lambda_{20}, \lambda_{21}, \lambda_{22}, S_{10}, S_{11}, S_{12}, S_{13}, S_{14}, S_{15}, S_{16}, S_{17}, S_{18}, S_{19}, S_{20}, S_{21}, S_{22}\right) \\
= & f(x)+\sum_{i=1}^{m} \lambda_{i} g_{i}(x)-\mathrm{b}+\mathrm{S}_{\mathrm{i}}^{2} \\
= & 10.700 x_{1}+3.400 x_{2}+6.450 x_{3}+6.300 x_{4}+7.700 x_{5}+6.600 x_{6}+7.200 x_{7} \\
& +\lambda_{1}\left(31,3 x_{1}+58,33 x_{2}+87,5 x_{3}+100 x_{4}+100 x_{5}+41,7 x_{7}+S_{1}^{2}-170.850\right)+\lambda_{2}\left(8 x_{1}+38 x_{3}\right. \\
& \left.+75 x_{4}+75 x_{5}+33,3 x_{7}+S_{2}^{2}-75.150\right)+\lambda_{3}\left(6,3 x_{1}+16,7 x_{2}+13 x_{3}+12,5 x_{4}+37,5 x_{5}+8,3 x_{7}\right. \\
& \left.+S_{3}^{2}-40.550\right)+\lambda_{4}\left(6,3 x_{1}+20,84 x_{2}+50 x_{3}+25 x_{4}+12,5 x_{5}+8,3 x_{7}+S_{4}^{2}-49.800\right)+\lambda_{5}\left(31,3 x_{1}\right. \\
& \left.+41,7 x_{6}+S_{5}^{2}-36.500\right)+\lambda_{6}\left(1,3 x_{1}+0,833 x_{2}+1,7 x_{7}+S_{6}^{2}-2.250\right)+\lambda_{7}\left(20,84 x_{2}+S_{7}^{2}\right. \\
& -18.750)+\lambda_{8}\left(41,67 x_{2}+S_{8}^{2}-37500\right)+\lambda_{9}\left(4,167 x_{2}+S_{9}^{2}-3.750\right)+\lambda_{10}\left(25 x_{3}+S_{10}^{2}-6250\right) \\
& +\lambda_{11}\left(62,5 x_{3}+S_{11}^{2}-15.650\right)+\lambda_{12}\left(50 x_{6}+S_{12}^{2}-25.000\right)+\lambda_{13}\left(12,5 x_{4}+37,5 x_{5}+S_{13}^{2}-15.000\right) \\
& +\lambda_{14}\left(125 x_{7}+S_{14}^{2}-62.500\right)+\lambda_{15}\left(43,8 x_{1}+41,67 x_{2}+25 x_{3}+50 x_{4}+16,7 x_{6}+S_{15}^{2}-89.000\right) \\
& +\lambda_{16}\left(x_{1}+S_{16}^{2}-500\right)+\lambda_{17}\left(x_{2}+S_{17}^{2}-900\right)+\lambda_{18}\left(x_{3}+S_{18}^{2}-250\right)+\lambda_{19}\left(x_{4}+S_{19}^{2}-300\right)+ \\
& \lambda_{20}\left(x_{5}+S_{20}^{2}-300\right)+\lambda_{21}\left(x_{6}+S_{21}^{2}-500\right)+\lambda_{22}\left(x_{7}+S_{22}^{2}-500\right)
\end{aligned}
$$

\subsubsection{Membentuk Persamaan Kuhn-Tucker}

Mengubah fungsi Lagrange pada persamaan (13) menjadi persamaan Kuhn-Tucker berikut :

$$
\frac{\partial \mathrm{L}}{\partial \mathrm{x}_{\mathrm{i}}}(x, \lambda, S)=0 \quad \frac{\partial \mathrm{L}}{\partial \lambda_{\mathrm{i}}}(x, \lambda, S)=0 \quad \frac{\partial \mathrm{L}}{\partial \mathrm{S}_{\mathrm{i}}}(x, \lambda, S)=0
$$

Sehingga diperoleh persamaan (14) sampai (65) berikut :

$$
\begin{aligned}
& \frac{\partial \mathrm{L}}{\partial \mathrm{x}_{1}}=10.700+31,3 \lambda_{1}+8 \lambda_{2}+6,3 \lambda_{3}+6,3 \lambda_{4}+31,3 \lambda_{5}+1,3 \lambda_{6}+43,8 \lambda_{15}+\lambda_{16}=0 \\
& \frac{\partial \mathrm{L}}{\partial \mathrm{x}_{2}}=3.400+58,33 \lambda_{1}+16,67 \lambda_{3}+20,84 \lambda_{4}+0,833 \lambda_{6}+20,84 \lambda_{7}+41,67 \lambda_{8}+4,167 \lambda_{9} \\
& +41,67 \lambda_{15}+\lambda_{17}=0 \\
& \frac{\partial \mathrm{L}}{\partial \mathrm{x}_{3}}=6.450+87,5 \lambda_{1}+38 \lambda_{2}+13 \lambda_{3}+50 \lambda_{4}+25 \lambda_{10}+62,5 \lambda_{11}+25 \lambda_{15}+\lambda_{18}=0 \\
& \frac{\partial \mathrm{L}}{\partial \mathrm{x}_{4}}=6.300+100 \lambda_{1}+75 \lambda_{2}+12,5 \lambda_{3}+25 \lambda_{4}+12,5 \lambda_{13}+50 \lambda_{15}+\lambda_{19}=0 \\
& \frac{\partial \mathrm{L}}{\partial \mathrm{x}_{5}}=7.700+100 \lambda_{1}+75 \lambda_{2}+37,5 \lambda_{3}+12,5 \lambda_{4}+37,5 \lambda_{13}+\lambda_{20}=0 \\
& \frac{\partial \mathrm{L}}{\partial \mathrm{x}_{6}}=6.600+41,7 \lambda_{5}+50 \lambda_{12}+16,7 \lambda_{15}+\lambda_{21}=0 \\
& \frac{\partial \mathrm{L}}{\partial \mathrm{x}_{7}}=7.200+41,7 \lambda_{1}+33,3 \lambda_{2}+8,3 \lambda_{3}+8,3 \lambda_{4}+1,7 \lambda_{6}+125 \lambda_{14}+\lambda_{22}=0 \\
& \frac{\partial \mathrm{L}}{\partial \lambda_{1}}=31,3 x_{1}+58,33 x_{2}+87,5 x_{3}+100 x_{4}+100 x_{5}+41,7 x_{7}+S_{1}^{2}-170.850=0 \\
& \frac{\partial \mathrm{L}}{\partial \lambda_{2}}=8 x_{1}+38 x_{3}+75 x_{4}+75 x_{5}+33,3 x_{7}+S_{2}^{2}-75.150=0 \\
& \frac{\partial \mathrm{L}}{\partial \lambda_{3}}=6,3 x_{1}+16,7 x_{2}+13 x_{3}+12,5 x_{4}+37,5 x_{5}+8,3 x_{7}+S_{3}^{2}-40.550=0 \\
& \frac{\partial \mathrm{L}}{\partial \lambda_{4}}=6,3 x_{1}+20,84 x_{2}+50 x_{3}+25 x_{4}+12,5 x_{5}+8,3 x_{7}+S_{4}^{2}-49.800=0
\end{aligned}
$$




$$
\begin{aligned}
& \frac{\partial \mathrm{L}}{\partial \lambda_{5}}=31,3 x_{1}+41,7 x_{6}+S_{5}^{2}-36.500=0 \\
& \frac{\partial \mathrm{L}}{\partial \lambda_{6}}=1,3 x_{1}+0,833 x_{2}+1,7 x_{7}+S_{6}^{2}-2.250=0 \\
& \frac{\partial \mathrm{L}}{\partial \lambda_{7}}=20,84 x_{2}+S_{7}^{2}-18.750=0 \\
& \frac{\partial \mathrm{L}}{\partial \lambda_{8}}=41,67 x_{2}+S_{8}^{2}-37.500=0 \\
& \frac{\partial \mathrm{L}}{\partial \lambda_{9}}=4,167 x_{2}+S_{9}^{2}-3.750=0 \\
& \frac{\partial \mathrm{L}}{\partial \lambda_{10}}=25 x_{3}+S_{10}^{2}-6250=0 \\
& \frac{\partial \mathrm{L}}{\partial \lambda_{11}}=62,5 x_{3}+S_{11}^{2}-15.650=0 \\
& \frac{\partial \mathrm{L}}{\partial \lambda_{12}}=50 x_{6}+S_{12}^{2}-25.000=0 \\
& \frac{\partial \mathrm{L}}{\partial \lambda_{13}}=12,5 x_{4}+37,5 x_{5}+S_{13}^{2}-15.000=0 \\
& \frac{\partial \mathrm{L}}{\partial \lambda_{14}}=125 x_{7}+S_{14}^{2}-62.500=0 \\
& \frac{\partial \mathrm{L}}{\partial \lambda_{15}}=43,8 x_{1}+41,67 x_{2}+25 x_{3}+50 x_{4}+16,7 x_{6}+S_{15}^{2}-89.000=0 \\
& \frac{\partial \mathrm{L}}{\partial \lambda_{16}}=x_{1}+S_{16}^{2}-500=0 \\
& \frac{\partial \mathrm{L}}{\partial \lambda_{17}}=x_{2}+S_{17}^{2}-900=0 \\
& \frac{\partial \mathrm{L}}{\partial \lambda_{18}}=x_{3}+S_{18}^{2}-250=0 \\
& \frac{\partial \mathrm{L}}{\partial \lambda_{19}}=x_{4}+S_{19}^{2}-300=0 \\
& \frac{\partial \mathrm{L}}{\partial \lambda_{20}}=x_{5}+S_{20}^{2}-300=0 \\
& \frac{\partial \mathrm{L}}{\partial \lambda_{21}}=x_{6}+S_{21}^{2}-500=0 \\
& \frac{\partial \mathrm{L}}{\partial \lambda_{22}}=x_{7}+S_{22}^{2}-500=0 \\
& \frac{\partial \mathrm{L}}{\partial \mathrm{S}_{1}}=2 S_{1}^{2} \lambda_{1}=0 \\
& \frac{\partial \mathrm{L}}{\partial \mathrm{S}_{2}}=2 S_{2}^{2} \lambda_{2}=0 \\
& \frac{\partial \mathrm{L}}{\partial S_{3}}=2 S_{3}^{2} \lambda_{3}=0 \\
& \frac{\partial \mathrm{L}}{\partial \mathrm{S}_{4}}=2 S_{4}^{2} \lambda_{4}=0 \\
& \frac{\partial \mathrm{L}}{\partial \mathrm{S}_{5}}=2 S_{5}^{2} \lambda_{5}=0 \\
& \frac{\partial \mathrm{L}}{\partial \mathrm{S}_{6}}=2 S_{6}^{2} \lambda_{6}=0 \\
& \frac{\partial \mathrm{L}}{\partial \mathrm{S}_{7}}=2 S_{7}^{2} \lambda_{7}=0 \\
& \frac{\partial \mathrm{L}}{\partial \mathrm{S}_{8}}=2 S_{8}^{2} \lambda_{8}=0 \\
& \frac{\partial \mathrm{L}}{\partial \mathrm{S}_{9}}=2 S_{9}^{2} \lambda_{9}=0 \\
& \frac{\partial \mathrm{L}}{\partial \mathrm{S}_{10}}=2 S_{10}^{2} \lambda_{10}=0 \\
& \frac{\partial \mathrm{L}}{\partial \mathrm{S}_{11}}=2 S_{11}^{2} \lambda_{11}=0 \\
& \frac{\partial \mathrm{L}}{\partial \mathrm{S}_{12}}=2 S_{12}^{2} \lambda_{12}=0 \\
& \frac{\partial \mathrm{L}}{\partial \mathrm{S}_{13}}=2 S_{13}^{2} \lambda_{13}=0 \\
& \frac{\partial \mathrm{L}}{\partial \mathrm{S}_{14}}=2 S_{14}^{2} \lambda_{14}=0 \\
& \frac{\partial \mathrm{L}}{\partial \mathrm{S}_{15}}=2 S_{15}^{2} \lambda_{15}=0 \\
& \frac{\partial \mathrm{L}}{\partial \mathrm{S}_{16}}=2 S_{16}^{2} \lambda_{16}=0
\end{aligned}
$$


$\frac{\partial \mathrm{L}}{\partial \mathrm{S}_{17}}=2 S_{17}^{2} \lambda_{17}=0$
$\frac{\partial \mathrm{L}}{\partial \mathrm{S}_{18}}=2 S_{18}^{2} \lambda_{18}=0$
$\frac{\partial \mathrm{L}}{\partial \mathrm{S}_{19}}=2 S_{19}^{2} \lambda_{19}=0$
$\frac{\partial \mathrm{L}}{\partial \mathrm{S}_{20}}=2 S_{20}^{2} \lambda_{20}=0$
$\frac{\partial \mathrm{L}}{\partial \mathrm{S}_{21}}=2 S_{21}^{2} \lambda_{21}=0$
$\frac{\partial \mathrm{L}}{\partial \mathrm{S}_{22}}=2 S_{22}^{2} \lambda_{22}=0$

Berdasarkan persamaan (43) sampai (65) diperoleh persamaan $2 \lambda_{i} S_{1}=0$, yang artinya salah satu variabel akan bernilai nol. Untuk mencari nilai $\lambda_{i}$ digunakan persamaan (14) sampai (20), maka persamaan (43) sampai (65) digunakan untuk mencari nilai $S_{i}$. Sehingga $S_{1}$ sampai $S_{22}$ bernilai nol. Nilai $S_{1}$ sampai $S_{22}$ akan berpengaruh pada nilai keuntungan yang maksimal/tertinggi. Selanjutnya mensubtitusikan/memasukkan nilai $S_{1}$ sampai $S_{22}$ ke persamaan (21) sampai (42), sehingga diperoleh persamaan (66) sampai (87) berikut :

$$
\begin{aligned}
& \frac{\partial \mathrm{L}}{\partial \lambda_{1}}=31,3 x_{1}+58,33 x_{2}+87,5 x_{3}+100 x_{4}+100 x_{5}+41,7 x_{7}-170.850=0 \\
& \frac{\partial \mathrm{L}}{\partial \lambda_{2}}=8 x_{1}+38 x_{3}+75 x_{4}+75 x_{5}+33,3 x_{7}-75.150=0 \\
& \frac{\partial \mathrm{L}}{\partial \lambda_{3}}=6,3 x_{1}+16,7 x_{2}+13 x_{3}+12,5 x_{4}+37,5 x_{5}+8,3 x_{7}-40.550=0 \\
& \frac{\partial \mathrm{L}}{\partial \lambda_{4}}=6,3 x_{1}+20,84 x_{2}+50 x_{3}+25 x_{4}+12,5 x_{5}+8,3 x_{7}-49.800=0 \\
& \frac{\partial \mathrm{L}}{\partial \lambda_{5}}=31,3 x_{1}+41,7 x_{6}-36.500=0 \\
& \frac{\partial \mathrm{L}}{\partial \lambda_{6}}=1,3 x_{1}+0,833 x_{2}+1,7 x_{7}-2.250=0 \\
& \frac{\partial \mathrm{L}}{\partial \lambda_{7}}=20,84 x_{2}-18.750=0 \\
& \frac{\partial \mathrm{L}}{\partial \lambda_{8}}=41,67 x_{2}-37.500=0 \\
& \frac{\partial \mathrm{L}}{\partial \lambda_{9}}=4,167 x_{2}-3.750=0 \\
& \frac{\partial \mathrm{L}}{\partial \lambda_{10}}=25 x_{3}-6250=0 \\
& \frac{\partial \mathrm{L}}{\partial \lambda_{11}}=62,5 x_{3}-15.650=0 \\
& \frac{\partial \mathrm{L}}{\partial \lambda_{12}}=50 x_{6}-25.000=0 \\
& \frac{\partial \mathrm{L}}{\partial \lambda_{13}}=12,5 x_{4}+37,5 x_{5}-15.000=0 \\
& \frac{\partial \mathrm{L}}{\partial \lambda_{14}}=125 x_{7}-62.500=0 \\
& \frac{\partial \mathrm{L}}{\partial \lambda_{15}}=43,8 x_{1}+41,67 x_{2}+25 x_{3}+50 x_{4}+16,7 x_{6}-89.000=0 \\
& \frac{\partial \mathrm{L}}{\partial \lambda_{16}}=x_{1}-500=0 \\
& \frac{\partial \mathrm{L}}{\partial \lambda_{17}}=x_{2}-900=0 \\
& \frac{\partial \mathrm{L}}{\partial \lambda_{18}}=x_{3}-250=0 \\
& \frac{\partial \mathrm{L}}{\partial \lambda_{19}}=x_{4}-300=0 \\
& \frac{\partial \mathrm{L}}{\partial \lambda_{20}}=x_{5}-300=0 \\
& \frac{\partial \mathrm{L}}{\partial \lambda_{21}}=x_{6}-500=0 \\
& \frac{\partial \mathrm{L}}{\partial \lambda_{22}}=x_{7}-500=0
\end{aligned}
$$

Berdasarkan persamaan (14) sampai (20) akan didapatkan nilai $\lambda_{i}$ dengan cara eliminasi persamaan tersebut, sehingga menghasilkan 22 persamaan yang dapat dibentuk menjadi persamaan linier untuk mendapatkan nilai $\lambda_{i}$. 22 Persamaan tersebut, yaitu persamaan (88) sampai (109) berikut : 


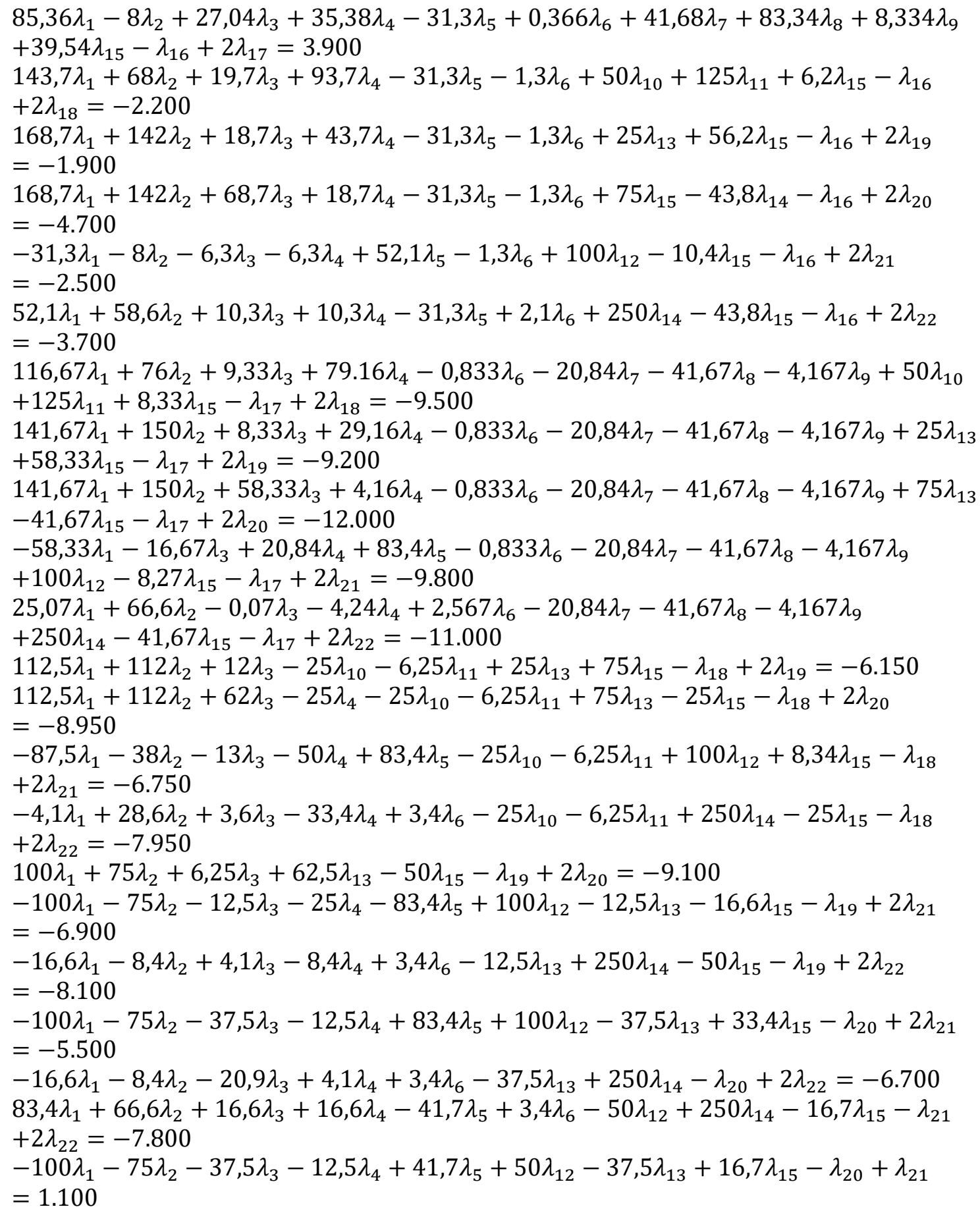

Berdasarkan persamaan (88) sampai (109) dapat dibentuk matriks $A_{22 \times 22}$ dan matriks $B_{22 \times 1}$ untuk mencari nilai $\lambda_{i}$. Matriks $A_{22 \times 22}$ yaitu matriks dari persamaan (88) sampai persamaan (109). 


\begin{tabular}{|c|c|c|}
\hline$A_{22 \times 22}$ & $=$ & \\
\hline$[85,36$ & -8 & 27,04 \\
\hline 143,7 & 68 & 19,7 \\
\hline 168,7 & 142 & 18,7 \\
\hline 168,7 & 142 & 68,7 \\
\hline$-31,3$ & -8 & $-6,3$ \\
\hline 52,1 & 58,6 & 10,3 \\
\hline 116,67 & 76 & 9,33 \\
\hline 141,67 & 150 & 8,33 \\
\hline 141,67 & 150 & 58,33 \\
\hline$-58,33$ & 0 & $-16,67$ \\
\hline 25,07 & 66,6 & $-0,07$ \\
\hline 112,5 & 112 & 12 \\
\hline 112,5 & 112 & 62 \\
\hline$-87,5$ & -38 & -13 \\
\hline$-4,1$ & 28,6 & 3,6 \\
\hline 100 & $\begin{array}{c}75 \\
-75\end{array}$ & 62,5 \\
\hline-100 & $\begin{array}{l}-75 \\
-84\end{array}$ & $-12,5$ \\
\hline$-16,6$ & $\begin{array}{l}-8,4 \\
-75\end{array}$ & 4,1 \\
\hline-100 & $\begin{array}{l}-15 \\
-84\end{array}$ & $-37,5$ \\
\hline$-16,6$ & $\begin{array}{l}-8,4 \\
66,6\end{array}$ & $-20,9$ \\
\hline 83,4 & -75 & $\begin{array}{c}16,6 \\
-375\end{array}$ \\
\hline
\end{tabular}

$\begin{array}{ccc}35,38 & -31,3 & 0,366 \\ 93,7 & -31,3 & -1,3 \\ 43,7 & -31,3 & -1,3 \\ 18,7 & -31,3 & -1,3 \\ -6,3 & 52,1 & -1,3 \\ 10,3 & -31,3 & 2,1 \\ 79,16 & 0 & -0,833 \\ 29,16 & 0 & -0,833 \\ 4,16 & 0 & -0,833 \\ -20,84 & 83,4 & -0,833 \\ -4,24 & 0 & 2,567 \\ 0 & 0 & 0 \\ -25 & 0 & 0 \\ -50 & 83,4 & 0 \\ -33,4 & 0 & 3,4 \\ 0 & 0 & 0 \\ -25 & 83,4 & 0 \\ -8,4 & 0 & 3,4 \\ -12,5 & 83,4 & 0 \\ 4,1 & 0 & 3,4 \\ 16,6 & -41,7 & 3,4 \\ -12,5 & 41,7 & 0\end{array}$

$\begin{array}{ccc}41,68 & 83,34 & 8,334 \\ 0 & 0 & 0 \\ 0 & 0 & 0 \\ 0 & 0 & 0 \\ 0 & 0 & 0 \\ 0 & 0 & 0 \\ -20,84 & -41,67 & -41,67 \\ -20,84 & -41,67 & -41,67 \\ -20,84 & -41,67 & -41,67 \\ -20,84 & -41,67 & -41,67 \\ -20,84 & -41,67 & -41,67 \\ 0 & 0 & 0 \\ 0 & 0 & 0 \\ 0 & 0 & 0 \\ 0 & 0 & 0 \\ 0 & 0 & 0 \\ 0 & 0 & 0 \\ 0 & 0 & 0 \\ 0 & 0 & 0 \\ 0 & 0 & 0 \\ 0 & 0 & 0 \\ 0 & 0 & 0\end{array}$

$\begin{array}{cc}0 & 0 \\ 50 & 125 \\ 0 & 0 \\ 0 & 0 \\ 0 & 0 \\ 0 & 0 \\ 50 & 125 \\ 0 & 0 \\ 0 & 0 \\ 0 & 0 \\ 0 & 0 \\ -25 & -62,5 \\ -25 & -62,5 \\ -25 & -62,5 \\ -25 & -62,5 \\ 0 & 0 \\ 0 & 0 \\ 0 & 0 \\ 0 & 0 \\ 0 & 0 \\ 0 & 0 \\ 0 & 0\end{array}$

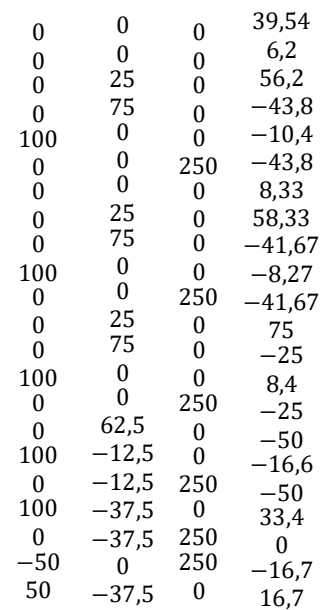

$\left.\begin{array}{ccccccc}-1 & 2 & 0 & 0 & 0 & 0 & 0 \\ -1 & 0 & 2 & 0 & 0 & 0 & 0 \\ -1 & 0 & 0 & 2 & 0 & 0 & 0 \\ -1 & 0 & 0 & 0 & 2 & 0 & 0 \\ -1 & 0 & 0 & 0 & 0 & 2 & 0 \\ -1 & 0 & 0 & 0 & 0 & 0 & 2 \\ 0 & -1 & 2 & 0 & 0 & 0 & 0 \\ 0 & -1 & 0 & 2 & 0 & 0 & 0 \\ 0 & -1 & 0 & 0 & 2 & 0 & 0 \\ 0 & -1 & 0 & 0 & 0 & 2 & 0 \\ 0 & -1 & 0 & 0 & 0 & 0 & 2 \\ 0 & 0 & -1 & 2 & 0 & 0 & 0 \\ 0 & 0 & -1 & 0 & 2 & 0 & 0 \\ 0 & 0 & -1 & 0 & 0 & 2 & 0 \\ 0 & 0 & -1 & 0 & 0 & 0 & 2 \\ 0 & 0 & 0 & -1 & 2 & 0 & 0 \\ 0 & 0 & 0 & -1 & 0 & 2 & 0 \\ 0 & 0 & 0 & -1 & 0 & 0 & 2 \\ 0 & 0 & 0 & 0 & -1 & 2 & 0 \\ 0 & 0 & 0 & 0 & -1 & 0 & 2 \\ 0 & 0 & 0 & 0 & 0 & -1 & 2 \\ 0 & 0 & 0 & 0 & -1 & 1 & 0\end{array}\right]$

Matriks $B_{22 \times 1}$, yaitu matriks dari nilai kanan pada persamaan (88) sampai persamaan (109).

$B_{22 \times 1}=$
$\left[\begin{array}{c}3.900 \\ -2.200 \\ -1.900 \\ -4.700 \\ -2.500 \\ -3.700 \\ -9.500 \\ -9.200 \\ -12.000 \\ -9.800 \\ -11.000 \\ -6.150 \\ -8.950 \\ -6.750 \\ -7.950 \\ -9.100 \\ -6.900 \\ -8.100 \\ -5.500 \\ -6.700 \\ -7.800 \\ 1.100\end{array}\right]$

Berdasarkan perkalian matriks, rumus untuk mencari nilai $\lambda_{i}$ yaitu $\lambda_{i}=A^{-1} B$, sehingga matriks $A_{22 \times 22}$ diinverskan terlebih dahulu [10]. Sehingga diperoleh:

$\mathrm{A}_{22 \times 22}^{-1}=$

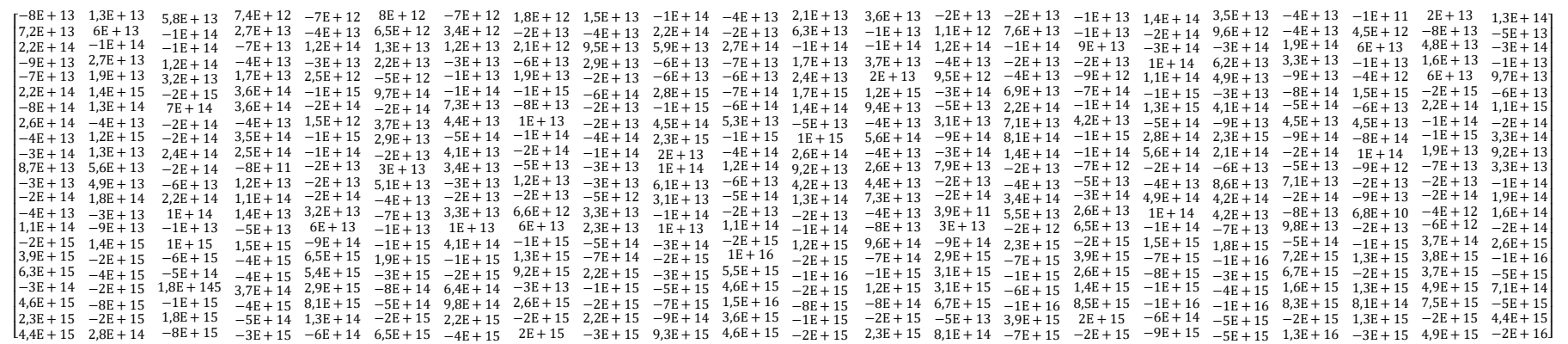

Selanjutnya, mengalikan $A_{22 \times 22}^{-1}$ dan $B_{22 x 1}$, sehingga didapatkan $\lambda_{i}$, yaitu $\lambda_{1}=-400, \lambda_{2}=-1.568$, $\lambda_{3}=2.752, \lambda_{4}=5.510, \quad \lambda_{5}=-144, \quad \lambda_{6}=26.624, \quad \lambda_{7}=-19.968, \lambda_{8}=3.168, \lambda_{9}=47.232, \lambda_{10}=$ $-10.384, \lambda_{11}=1.600, \lambda_{12}=688, \lambda_{13}=-736, \lambda_{14}=-288, \lambda_{15}=-1.184, \lambda_{16}=8.704, \lambda_{17}=26.624$, $\lambda_{18}=-32.768, \lambda_{19}=41.856, \lambda_{20}=-30.720, \lambda_{21}=-13.312$, dan $\lambda_{22}=-12.288$. Berdasarkan Tabel 1, syarat cukup metode Kuhn-Tucker dalam masalah linier yaitu nilai $\lambda_{i}$ tidak terbatas tanda yang artinya $\lambda_{i} \geq 0$ dan $\lambda_{i} \leq 0$, maka masalah linier dalam optimasi ini memenuhi syarat cukup metode Kuhn-Tucker. Selanjutnya, dalam mencari nilai $x_{1}, x_{2}, x_{3}, x_{4}, x_{5}, x_{6}, x_{7}$ dapat digunakan persamaan (72), (75), (77), (70), (79), (80), dan (78). Sehingga diperoleh $x_{1}=500, x_{2}=900, x_{3}=250, x_{4}=300, x_{5}=300, x_{6}=$ $500, x_{7}=500$. 


\subsubsection{Menghitung Nilai Keuntungan yang Maksimal/Tertinggi}

Mensubtitusikan/memasukkan nilai $\left(x_{i}, \lambda_{i}, S_{i}\right)$ kedalam fungsi Lagrange yang telah dibentuk untuk mendapatkan keuntungan yang maksimal/tertinggi, sehingga diperoleh:

$$
\begin{aligned}
& L\left(x_{i}, \lambda_{i}, S_{i}\right)=f(x)+\sum_{i=1}^{m} \lambda_{i} g_{i}(x)-\mathrm{b}+\mathrm{S}_{\mathrm{i}}^{2} \\
& \mathrm{~L}\left(x_{1}, x_{2}, x_{3}, x_{4}, x_{5}, x_{6}, x_{7}, \lambda_{1}, \lambda_{2}, \lambda_{3}, \lambda_{4}, \lambda_{5}, \lambda_{6}, \lambda_{7}, \lambda_{8}, \lambda_{9}, \lambda_{10}, \lambda_{11}, \lambda_{12}, \lambda_{13}, \lambda_{14}, \lambda_{15}, \lambda_{16}, \lambda_{17}\right. \\
&\left., \lambda_{18}, \lambda_{19}, \lambda_{20}, \lambda_{21}, \lambda_{22}, S_{10}, S_{11}, S_{12}, S_{13}, S_{14}, S_{15}, S_{16}, S_{17}, S_{18}, S_{19}, S_{20}, S_{21}, S_{22}\right) \\
&=f(x)+\sum_{i=1}^{m} \lambda_{i} g_{i}(x)-\mathrm{b}+\mathrm{S}_{\mathrm{i}}^{2} \\
&=10.700(500)+3.400(900)+6.450(250)+6.300(300)+7.700(300)+6.600(500)+7.200(500) \\
&-400(31,3(500)+58,33(900)+87,5(250)+100(300)+100(300)+41,7(500)+0-170.850) \\
&-1.568(8(500)+38(250)+75(300)+75(300)+33,33(500)+0-75.150)+2.752(6,3(500) \\
&+16,67(900)+13(250)+12,5(300)+37,5(300)+8,3(500)+0-40.550)+5.510(6,3(500) \\
&+20,84(900)+50(250)+25(300)+12,5(300)+8,3(500)+0-49.800)-144(31,3(500) \\
&+41,7(500)+0-36.500)+26.624(1,3(500)+0,833(900)+1,7(500)+0-2.250)-19.968 \\
&(20,84(900)+0-18.750)+3.168(41,67(900)+0-37.500) \\
&+47.232(4,167(900)+0-3.750)-10.384(25(250)+0-6250) \\
&+1.600(62,5(250)+0-15.650)-688(50(500)+0-25.000)-736 \\
&(12,5(300)+37,5(300)+0-15.000)-288(125(500)+0-62.500)-1.184 \\
&(43,8(500)+41,67(900)+25(250)+50(300)+16,7(500)+0-89.000)+8.704 \\
&(500+0-500)+26.624(900+0-900)-32.768(250+0-250)+41.856(300+0-300) \\
&-30.720(300+0-300)-13.312(500+0-500)-12.288(500+0-500) \\
&= 21.122 .500
\end{aligned}
$$

\section{KESIMPULAN}

Berdasarkan hasil dan pembahasan dapat diberikan kesimpulan bahwa model matematika program linier dalam optimasi ini, yaitu fungsi tujuan berupa keuntungan produksi 7 jenis produk kue kering dan fungsi kendala berupa 15 bahan baku produk kue kering dalam kemasan 250 gram dan 7 jumlah produk kue kering yang dihasilkan pada tahun 2019 di Home Industry Comod Cookies. Model matematika program linier ini dapat dianalisis menggunakan metode Kuhn-Tucker, sehingga menghasilkan keuntungan produksi kue kering di Home Industry Comod Cookies sudah optimal. Keuntungan yang maksimal/tertinggi sebesar Rp. 21.122.500,00 dalam memproduksi 7 jenis kue kering, yaitu Rambutan Cookies $\left(x_{1}\right)$ sebanyak 500 kemasan,Cheerful Chips $\left(x_{2}\right)$ sebanyak 900 kemasan, Laugh Nut $\left(x_{3}\right)$ sebanyak 250 kemasan, Snowny Cheese $\left(x_{4}\right)$ sebanyak 300 kemasan, Cheese Cookies $\left(x_{5}\right)$ sebanyak 300 kemasan, Happy Corn $\left(x_{6}\right)$ sebanyak 500 kemasan, dan Nastar Cookies $\left(x_{7}\right)$ sebanyak 500 kemasan.

\section{DAFTAR PUSTAKA}

[1] Y. Siadari, Optimasi Keuntungan dalam Produksi Industri Keripik Di Gang PU Bandar Lampung (Studi Kasus: Istana Keripik Pisang Ibu Mery). PhD [Skripsi]. Bandar Lampung: Univ. Lamp., 2016. [Online]. Available: https://adoc.pub/queue/optimasikeuntungan-dalam-produksi-industri-keripik-di-gang-.html.

[2] A. Sa'ban, Penerapan Metode Kuhn Tucker untuk Optimalisasi Produksi. PhD [Skripsi]. Malang: UIN Maul. Malik Ibr., 2020. [Online]. Available: http://etheses.uin-malang.ac.id/20942/1/13610036.pdf.

[3] BPS, Kabupaten Blitar dalam Angka 2021. Blitar: BPS Kabupaten Blitar, 2021.

[4] C. E. Ayuningtyas, "Preferensi Konsumen terhadap Organoleptik Cookies Non Terigu," J. Nutr. Food Res., vol. 42, no. 2, pp. 81-86, 2019.

[5] S. Aprilyanti, "Optimasi Keuntungan Produksi Pada Industri Kayu Pt . Indopal Harapan Murni Menggunakan Linear,” Pasti, vol. 13, no. 1, pp. 1-8, 2019.

[6] Suryanto, E. S. Nugroho, and R. A. K. Putra, "Analisis optimasi keuntungan dalam produksi keripik daun singkong dengan linier programming melalui metode simpleks," J. Manaj., vol. 11, no. 2, pp. 226-236, 2019.

[7] Taufiqurrachman, "Program Linear dengan Metode Simplex," Riset Operasional, Jakarta: Fakultas Teknik Universitas Esa Unggul, 2016, 1-16.

[8] Indriani, Suyitno, and Mashuri, “Analisis Metode Karmarkar Untuk Menyelesaikan Masalah Program Linier,” J. MIPA, vol. 36, no. 1, pp. 98-106, 2013.

[9] N. M. Asih and I. N. Widana, "Aplikasi Metode Khun Tucker dalam Penjualan Oli Mobil ( Studi Kasus : PT . Anugrah Mitra Dewata )," J. Mat., vol. 2, no. 1, pp. 57-68, 2012. 
[10] E. Safitri, S. Basriati, and A. Zahara, "Optimalisasi Hasil Produksi Menggunakan Metode Kuhn-Tucker ( Studi Kasus : Toko Baju Mitra Pekanbaru ),” J. Sains Mat. dan Stat. J. Has. Penelit. Mat. Stat. dan Apl., vol. 5, no. 1, pp. 30-39, 2019.

[11] I. G. A. J. Putra, N. M. Asih, and I. N. Widana, "Optimalisasi Penjualan Kain Endek Dengan Metode Karush-Kuhn-Tucker (Kkt)," E-Jurnal Mat., vol. 4, no. 4, p. 158, 2015, doi: 10.24843/mtk.2015.v04.i04.p105.

[12] C. Tanujaya, "Perancangan Standart Operational Procedure Produksi pada Perusahaan Coffeein," J. Manag. dan Start-Up Bisnis, vol. 2, no. 1, 2017

[13] E. A. Putra, "Anak Berkesulitan Belajar di Sekolah Dasar Se-Kelurahan Kalumbuk Padang (Penelitian Deskriptif Kuantitatif)," J. Ilm. Pendidik. Khusus, vol. 4, no. September, pp. 71-76, 2015.

[14] M. Hilman, "Optimasi Jumah Produksi Produk Furniture Pada Pd . Surya Mebel Di Kecamatan Cipaku Dengan Metode Linier Programming," vol. 03, no. 01, pp. 85-97, 2016.

[15] I. Nuryana, "Optimasi Jumlah Produksi pada UMKM Raina Kersen dengan Metode Linear Programming,” J. Media Teknol., vol. 6, no. 1, pp. 67-90, 2019. 
